\title{
Performance Evaluation of Single Cylinder Diesel Engine Using Tyre Pyrolysis Oil (TPO) Blends
}

\author{
P M Bhatt \\ Mechanical Department, Gujarat technological University \\ Government Polytechnic, Ahmedabad, Gujarat, India \\ pmbhatt009@gmail.com
}

\begin{abstract}
Increasing industrialization and motorization led to a significant rise in demand of petroleum products. As these are the nonrenewable resources, it will be troublesome to predict the availability of these resources in the future, resulting in uncertainty in its supply and price and is impacting growing economies like India importing $80 \%$ of the total demand of the petroleum products. Many attempts have been made by different researchers to find out alternate fuels for Internal Combustion engines. Many alternate fuels like Biodiesel, LPG (Liquefied Petroleum Gas), CNG (Compressed Natural Gas) and Alcohol are being used nowadays by different vehicles. In this context pyrolysis of scrap tyres can be used effectively to produce oil, thereby solving the problem of waste tyre disposal. In the present study, Experimental investigations were carried out to evaluate the performance and emission characteristics of a single cylinder diesel engine fueled by TPO10, TPO15, and TPO20 at a crank angle $28^{\circ}$ before TDC (Top Dead Centre) and injection pressure of 180 bar keeping the blend quality by controlling the density and viscosity of tyre pyrolysis oil within permissible limit of euro IV diesel requirement. The performance and emission results were analyzed and compared with that of diesel fuel operation. The results of investigations indicate that the brake thermal efficiency of the TPO - DF blend decreases by 4 to $8 \%$. CO emissions are slightly higher but within permissible limit of euro IV emission standards. HC emissions are higher by about 40 to $60 \%$ at partial load whereas smoke opacity is lower by about $14 \%$ to $22 \%$ as compared to diesel fuel.
\end{abstract}

Keywords- Experimental Investigation, Diesel Engine, Tyre Pyrolysis Oil (TPO), Performance, Emission

$* * * * *$

\section{INTRODUCTION}

Petroleum based fuels are stored fuels in the earth. There are limited reserves of these stored fuels and they are irreplaceable. This finite resource of petroleum are highly concentrated in certain regions of the world, have given rise to uncertainty in its supply and price and is impacting growing economies like India, importing $80 \%$ of the total demand of crude. India's petroleum product consumption has increased from 100.4 million tonnes in 2001-02 to 133.4 million tonnes in 2008-09 at a CAGR of $4.1 \%$ and is likely to increase up to 217 million tonnes by 2020-21 and 325.6 million tonnes by 2030-31. All over the world, there are initiatives to replace gasoline and diesel fuel due to the impact of the fossil fuel crisis and hike in oil price. Millions of dollars are being invested in the search for alternative fuels. On the other hand, the disposal of waste tyres from automotive vehicles is becoming more and more complex. Waste to energy is the recent trend in the selection of alternate fuels. Fuels like alcohol, biodiesel, liquid fuel from plastics, etc. are some of the alternative fuels for the internal combustion engines. In order to prevent waste rubber and in particular discarded automobile tyres from damaging the environment, it is highly desirable to recycle this material in a useful manner. However, the total quantity of tyres currently recycled in a given year (excluding reuse, retreading, or combustion) is less than $7 \%$ of the annual tyre generation rate in the world. The use of tyre pyrolysis oil as a substitution of diesel fuel is an opportunity in minimizing the utilization of the natural resources. Several research works have been carried out on the pyrolysis of waste automobile tyres. Pyrolysis is the process of thermally degrading a substance into smaller, less complex molecules. Pyrolysis produces three principle products: such as pyrolytic oil, gas and char. The quality and quantity of these products depend upon the reactor temperature and design. In the Pyrolysis process, larger hydrocarbon chains break down at certain temperatures in the absence or a limited supply of oxygen that gives end products usually containing solids, liquids and gases. If the temperature is maintained at $550{ }^{\circ} \mathrm{C}$, the main product is a liquid, which could be a mixture of various hydrocarbons depending on the initial composition of the waste material. At temperatures above $700{ }^{\circ} \mathrm{C}$, the gas becomes the primary product due to further cracking of liquids. The gas is basically composed of $\mathrm{CH}_{4}$, with $\mathrm{C}_{2} \mathrm{H}_{6}$, $\mathrm{C}_{2} \mathrm{H}_{4}, \mathrm{C}_{2} \mathrm{H}_{2}$, and other gaseous hydrocarbons however in lesser quantities. In the present work pyrolysis oil from waste tyres by pyrolysis is obtained and used as a blended fuel in stationary diesel engine. Though solid carbon black and pyrolysis gas are also obtained, the pyrolysis process will be much more prominent to produce liquid ${ }^{[1,2,3,4}$, and 5]. 


\section{PREPARATION AND TESTING OF TYRE OIL}

\section{A. Pyrolysis of Waste Automobile Tyres}

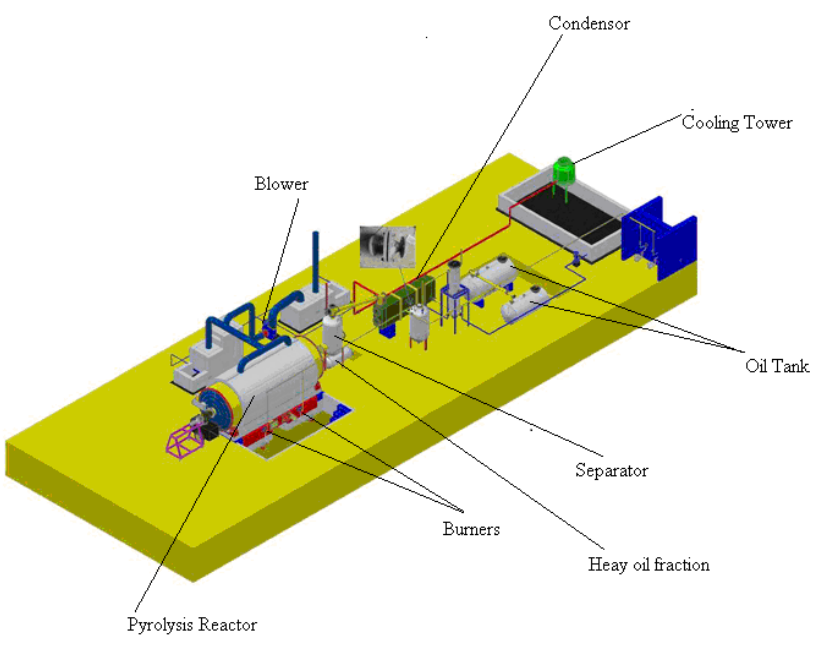

Fig. 1 Waste Tyre Recycling Pyrolysis Plant

Pyrolysis is a Thermo chemical decomposition of organic material at elevated temperature in the absence of oxygen. Pyrolysis typically occurs under pressure and at operating temperatures about $430^{\circ} \mathrm{C}$ in a batch process system. In the present work waste automobile tyres were fed into 5Tonnes capacity rotary horizontal direct heating reactor vessel as shown in figure 1. Initially the heat was supplied by means of oil under controlled conditions of temperature and pressure. The process resulted in molecular restructuring of rubber and converted into vapours and gases. These vapours and gases came in to separator where heavy oil fraction was separated from gases and the gases were passed through the series of heat exchangers to condense the vapour into liquid form, called tyre oil (40 to $45 \%$ ) by means of recirculated water from cooling tower and is collected into the storage tank. Non condensable gases also called Pyro gases (about $10 \%$ ) were used for heating the reactor in place of oil, initially used for heating purpose as per the requirement and the rest of the gases were burnt in the open air by means of gas burner. During the process carbon black (30 to 35\%) and steel wires (10 to $15 \%$ ) were also generated.

\section{B. Fuel Composition and Properties}

Tyre oil derived from pyrolysis process was tested in the laboratory for determination of its Physio-chemical properties as compared to standard values for diesel as shown in the table 1 . The liquids obtained are dark brown colored products, resembling petroleum fractions.
Table I

Comparison of Properties of TPO with standard value for Diesel

\begin{tabular}{|c|c|c|c|c|}
\hline $\begin{array}{l}\text { SR. } \\
\text { NO } \\
\text {. }\end{array}$ & $\begin{array}{c}\text { SPECIFICATIO } \\
\text { NS }\end{array}$ & UNITS & $\begin{array}{c}\text { TEST } \\
\text { RESULTS }\end{array}$ & $\begin{array}{c}\text { STANDARD } \\
\text { VALUE OF } \\
\text { DIESEL } \\
\text { (IS:1460) }\end{array}$ \\
\hline 1 & $\begin{array}{c}\text { KINEMATIC } \\
\text { VISCOSITY AT } \\
40^{\circ} \mathrm{C}\end{array}$ & $\mathrm{cSt}$ & 8.65 & $2.0-4.5$ \\
\hline 2 & $\begin{array}{c}\text { ACIDITY, } \\
\text { INORGANIC }\end{array}$ & $\begin{array}{l}\mathrm{mgKOH} \\
\operatorname{lgm}\end{array}$ & 0.14 & NIL \\
\hline 3 & $\mathrm{ASH}$ & $\begin{array}{l}\% \text { by } \\
\text { mass }\end{array}$ & 0.04 & $0.01 \mathrm{MAX}$ \\
\hline 4 & $\begin{array}{l}\text { FLASH POINT, } \\
\text { ABLES/PMCC }\end{array}$ & ${ }^{\circ} \mathrm{C}$ & 32 & $\begin{array}{l}35 \mathrm{MIN} / \\
66 \mathrm{MIN}\end{array}$ \\
\hline 5 & $\begin{array}{c}\text { WATER } \\
\text { CONTENT }\end{array}$ & $\mathrm{mg} / \mathrm{kg}$ & NIL & 200 MAX \\
\hline 6 & POUR POINT & ${ }^{\circ} \mathrm{C}$ & +6 & 3 Min \\
\hline 7 & $\begin{array}{c}\text { DENSITY AT } \\
15^{\circ} \mathrm{C}\end{array}$ & $\mathrm{kg} / \mathrm{cm}^{3}$ & 0.910 & $0.820-0.845$ \\
\hline 8 & SEDIMENTS & $\begin{array}{c}\mathrm{Mg} / 100 \\
\mathrm{ml}\end{array}$ & NIL & --- \\
\hline 9 & $\begin{array}{c}\text { TOTAL } \\
\text { SULPHUR }\end{array}$ & $\mathrm{mg} / \mathrm{kg}$ & 88 & 50 MAX \\
\hline 10 & $\begin{array}{c}\text { CARBON } \\
\text { RESIDUE, } \\
\text { RAMSBOTTOM }\end{array}$ & $\%$ & 0.85 & $0.30 \mathrm{MAX}$ \\
\hline 11 & $\begin{array}{c}\text { COPPER STRIP } \\
\text { CORROSION } \\
\text { TEST FOR } 3 \\
\text { HRS AT } 100^{\circ} \mathrm{C}\end{array}$ & --- & $1 \mathrm{a}$ & $<1$ \\
\hline 12 & $\begin{array}{l}\text { DISTILATION, } \\
\text { RECOVERY OF } \\
95 \% \mathrm{AT}^{\mathrm{O}} \mathrm{C}\end{array}$ & ${ }^{\mathrm{O}} \mathrm{C}$ & 390 & 360 MAX \\
\hline 13 & $\begin{array}{l}\text { COLOUR } \\
\text { INDEX }\end{array}$ & --- & DARK & TO REPORT \\
\hline 14 & $\begin{array}{c}\text { CETANE } \\
\text { NUMBER, } \\
\text { DIESEL INDEX }\end{array}$ & --- & 42 & $51 \mathrm{MIN}$. \\
\hline 15 & $\begin{array}{l}\text { ACIDITY, } \\
\text { TOTAL }\end{array}$ & $\begin{array}{l}\operatorname{mgKOH} \\
/ \mathrm{gm}\end{array}$ & NIL & TO REPORT \\
\hline 16 & $\begin{array}{c}\text { POLYCYCLIC } \\
\text { AROMATIC } \\
\text { HYDROCARBO } \\
\text { N }\end{array}$ & $\begin{array}{l}\% \text { by } \\
\text { mass }\end{array}$ & 24 & 11 \\
\hline
\end{tabular}


Hence pyrolysis of scrap tyres produces oil that can be used as liquid fuel for industrial furnaces, foundries and boilers in power plants due to their higher calorific value, low ash, and moisture content as far as sulphur content of oil is not a problem. However, higher density, Kinematic viscosity and Lower Cetane number of tyre oil suggest that the behaviour of tyre oil in Internal Combustion Engine can be studied by improving its quality in terms of reduction in density, viscosity, sulphur and aromatic contents by proper distillation and processing of tyre oil, if tyre oil is to be used as a fuel in Internal Combustion Engine.

\section{Refining tyre oil}

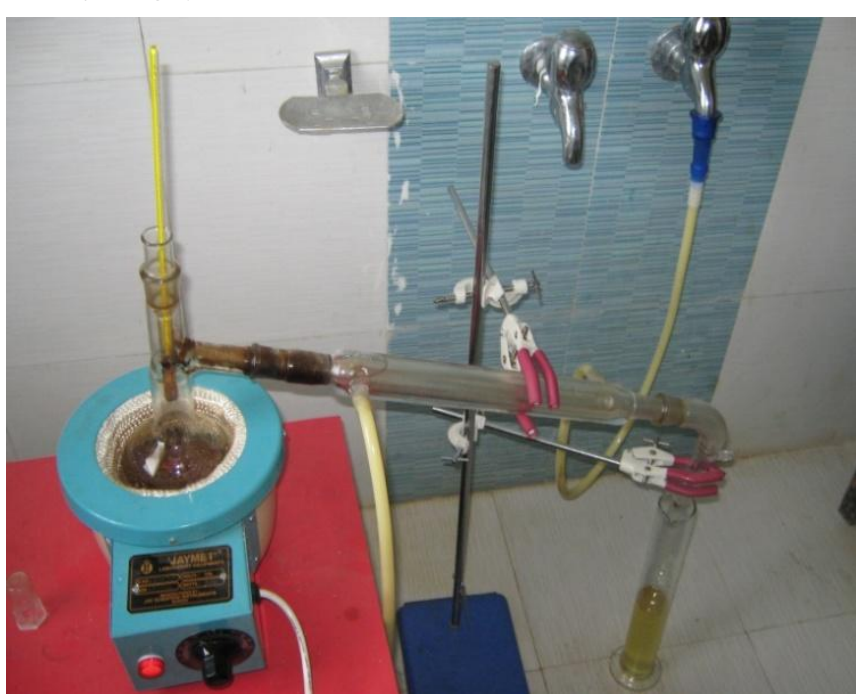

Fig. 2 Distillation Apparatus

Fractional distillation of tyre oil was carried out in the boiling range of diesel in a distillation apparatus shown in figure 2 in which a flask containing tyre oil was heated by means of heating mental in the temperature range of $1500 \mathrm{C}$ to $3700 \mathrm{C}$. The vapours formed were cooled by means of circulating water in an inclined condenser and condensed oil was collected in a measuring cylinder. Collected oil was mixed with concentrated hydro sulphuric acid on a volumetric basis in suitable proportion to reduce sulphur and aromatic content of oil. The oil was then neutralized and filtered by means of fine filter paper and stored in a plastic container. The refined oil was tested in the laboratory for determination of its Physio-chemical properties as compared to standard values for diesel as shown in the table 2
Table II

Comparison of Properties of Refined TPO with standard value for Diesel

\begin{tabular}{|c|c|c|c|c|}
\hline $\begin{array}{l}\text { SR. } \\
\text { NO. }\end{array}$ & SPECIFICATIONS & UNITS & $\begin{array}{c}\text { TEST } \\
\text { RESULTS }\end{array}$ & $\begin{array}{l}\text { STANDARD } \\
\text { VALUE OF } \\
\text { DIESEL } \\
\text { (IS:1460) }\end{array}$ \\
\hline 1 & $\begin{array}{c}\text { KINEMATIC } \\
\text { VISCOSITY AT } \\
40^{\circ} \mathrm{C}\end{array}$ & $\mathrm{cSt}$ & 2.30 & $2.0-4.5$ \\
\hline 2 & $\begin{array}{l}\text { ACIDITY, } \\
\text { INORGANIC }\end{array}$ & $\mathrm{mgKOH} / \mathrm{gm}$ & NIL & NIL \\
\hline 3 & ASH & $\%$ by mass & 0.01 & 0.01 MAX \\
\hline 4 & $\begin{array}{l}\text { FLASH POINT, } \\
\text { ABLES/PMCC }\end{array}$ & ${ }^{\circ} \mathrm{C}$ & $<30$ & $\begin{array}{l}\text { 35MIN/ } \\
66 \mathrm{MIN} . .\end{array}$ \\
\hline 5 & $\begin{array}{l}\text { WATER } \\
\text { CONTENT }\end{array}$ & $\mathrm{mg} / \mathrm{kg}$ & NIL & 200 MAX \\
\hline 6 & POUR POINT & ${ }^{\circ} \mathrm{C}$ & +3 & $3 \mathrm{Min}$ \\
\hline 7 & $\begin{array}{c}\text { DENSITY AT } 15^{\circ} \\
\text { C }\end{array}$ & $\mathrm{kg} / \mathrm{cm}^{3}$ & 0.820 & $0.820-0.845$ \\
\hline 8 & SEDIMENTS & $\mathrm{Mg} / 100 \mathrm{ml}$ & NIL & --- \\
\hline 9 & $\begin{array}{l}\text { TOTAL } \\
\text { SULPHUR }\end{array}$ & $\mathrm{mg} / \mathrm{kg}$ & 0.35 & $50 \mathrm{MAX}$ \\
\hline 10 & $\begin{array}{c}\text { CARBON } \\
\text { RESIDUE, } \\
\text { RAMSBOTTOM }\end{array}$ & $\%$ & 0.25 & 0.30 MAX \\
\hline 11 & $\begin{array}{l}\text { COPPER STRIP } \\
\text { CORROSION } \\
\text { TEST FOR } 3 \text { HRS } \\
\text { AT } 100^{\circ} \mathrm{C}\end{array}$ & --- & 1a & $<1$ \\
\hline 12 & $\begin{array}{l}\text { DISTILATION, } \\
\text { RECOVERY OF } \\
92 \% \mathrm{AT}^{\circ} \mathrm{C}\end{array}$ & ${ }^{\circ} \mathrm{C}$ & 360 & 360 MAX \\
\hline 13 & COLOUR INDEX & --- & 5 & TO REPORT \\
\hline 14 & $\begin{array}{l}\text { CETEN NUMBER, } \\
\text { DIESEL INDEX }\end{array}$ & --- & 44 & $51 \mathrm{MIN}$. \\
\hline 15 & ACIDITY, TOTAL & $\mathrm{mgKOH} / \mathrm{gm}$ & NIL & TO REPORT \\
\hline 16 & $\begin{array}{c}\text { POLYCYCLIC } \\
\text { AROMATIC } \\
\text { HYDROCARBON }\end{array}$ & $\%$ by mass & 7 & 11 \\
\hline
\end{tabular}


From the table it is clear that almost all the properties of refined tyre oil are more or less within permissible limit of Euro IV diesel specifications except flash point and Cetane number, which suggests that the behavior of tyre oil in Internal Combustion Engine can be studied through blending Tyre oil with DF on volume basis. In the present work $10 \%$, $15 \%$, and $20 \%$, of TPO is blended with DF on a volume basis and observed for 15 days to check for any separation. No such separation was noticed. TPO blended with DF is indicated as TPO xx. For example, the $10 \%$ TPO blended with $90 \% \mathrm{DF}$ is denoted as TPO 10.

\section{EXPERIMENTAL DETAILS}

In the present work single cylinder water cooled diesel engines as shown in figure 3 is used for studying the performance and emission characteristics of the TPO - DF blend at a crank angle of $28^{\circ}$ before TDC injection timing and 180 bar injection pressure. The specifications of the engine are shown in table 3 . The fuel flow rate was measured on a volumetric basis using a burette and a stop watch. The air flow rate was measured by connecting the air intake to a large rigid box with an orifice at its inlet to damp out pulsations in flow and by measuring the pressure drop across orifice by means of the water tube manometer.

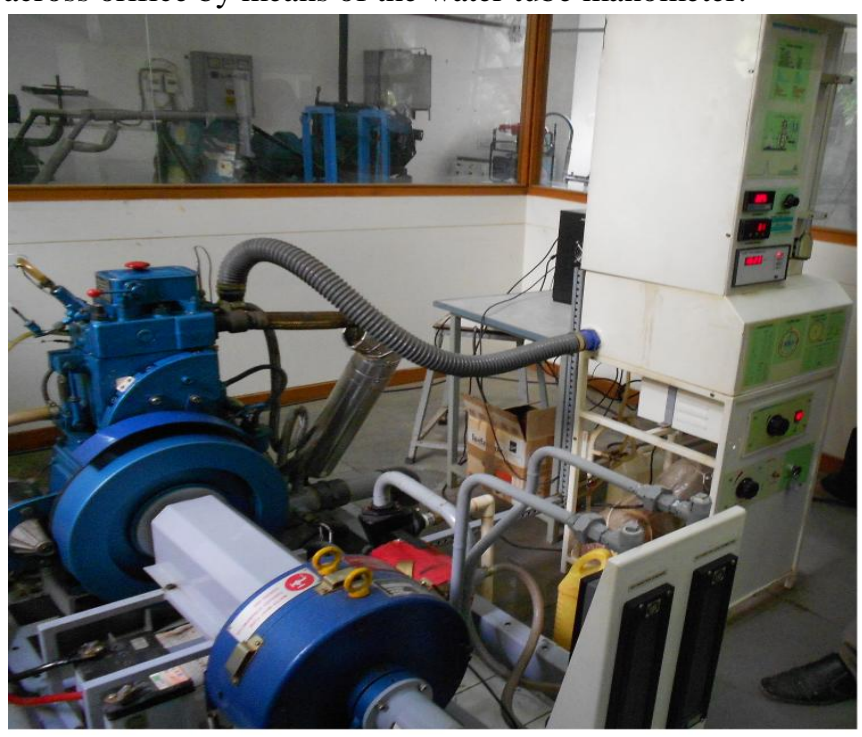

Fig. 3 Single Cylinder Diesel Engine Test rig

Table III

Engine Details

\begin{tabular}{|c|c|}
\hline Name of the Engine & Captain \\
\hline General Details & $\begin{array}{c}\text { Four stroke, CI, Water cooled, Single } \\
\text { Cylinder }\end{array}$ \\
\hline Rated Power kw/bhp & $3.7 / 5.0$ \\
\hline Rated Speed(rpm) & 1500 \\
\hline Bore $(\mathrm{mm})$ & 87.5 \\
\hline Stroke $(\mathrm{mm})$ & 110 \\
\hline
\end{tabular}

\begin{tabular}{|c|c|}
\hline Compression Ratio & $16.5: 1$ \\
\hline Dynamometer & $\begin{array}{c}\text { Eddy current, water cooled with } \\
\text { loading unit }\end{array}$ \\
\hline Fuel oil & HSD \\
\hline Lubricant & SAE 30/40 \\
\hline
\end{tabular}

Thermocouple with $\mathrm{K}$ type probe having temperature range $0-1200^{\circ} \mathrm{C}$ and accuracy $0.4 \%$ of the reading above $0^{\circ} \mathrm{C}$ in conjunction with a digital temperature indicator was used to measure the exhaust gas and cooling water temperature. Whereas sling Psychrometer was used to measure dry bulb and wet bulb temperature of the surrounding. Laser photo tachometer having 5 digits, $10 \mathrm{~mm}$ LCD display and range 10 to 99,999 RPM with accuracy $\pm 0.05 \%+1$ digit was used for speed measurement. A Non dispersive Infrared 4-gas analyzer was used to measure emissions in the exhaust. $\mathrm{CO}$ was measured in percentage volume. $\mathrm{HC}$ was measured in ppm volume. Smoke opacity was measured using a diesel smoke meter. All the tests were conducted by starting the engine with DF only. After the engine was warmed up, it was then switched to TPO-DF blend. At the end of the test, the fuel was switched back to diesel and the engine was kept running for some time to flush out the TPO-DF blend by DF from the fuel line and the injection system, in order to prevent the fuel system from the accumulation of TPO-DF which may damage the system.

\section{RESULTS AND DISCUSSIONS}

\section{A. Performance Characteristics}

\section{Brake Thermal Efficiency:}

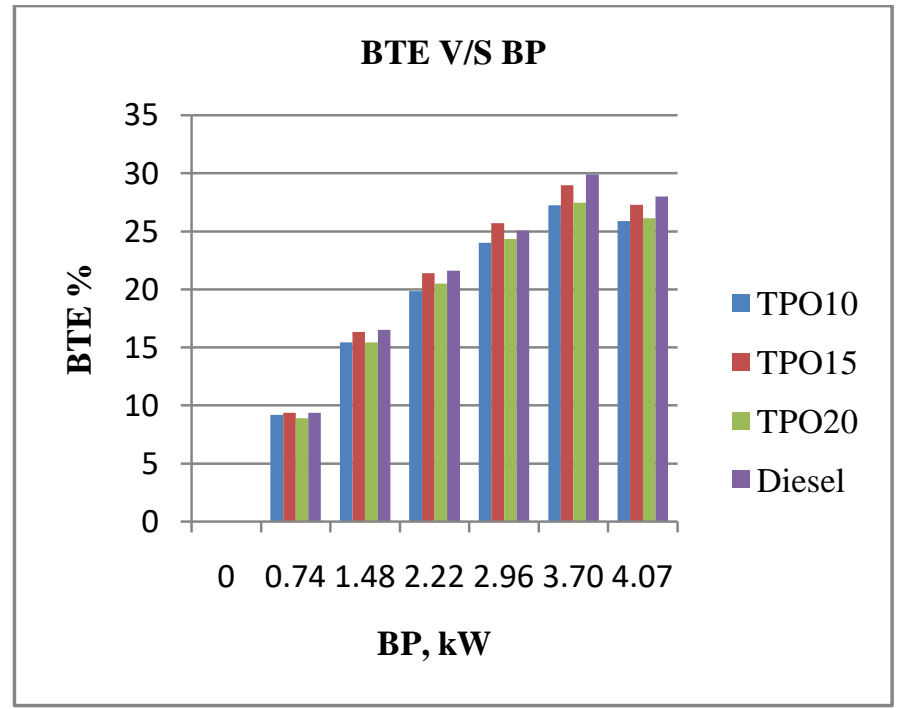

Fig. 4 Variations in Brake Thermal Efficiency with Brake Power Figure.4 shows variation in Brake thermal efficiency with Brake power. It may be determined from the figure that the thermal efficiency of TPO 10, TPO 15 and TPO 20 is lower than that of diesel fuel (DF). This may be due to lower viscosity of TPO which results in improper penetration of 
fuel spray into the combustion chamber and inferior combustion.

\section{Specific Energy Consumption:}

Figure.5 shows variation in Specific energy consumption with Brake power. It may be determined from the figure that specific energy consumption is higher for TPO 10, TPO 15 and TPO 20 as compared to Diesel fuel. This may be due to lower calorific value of the TPO - DF blend as compared to Diesel fuel.

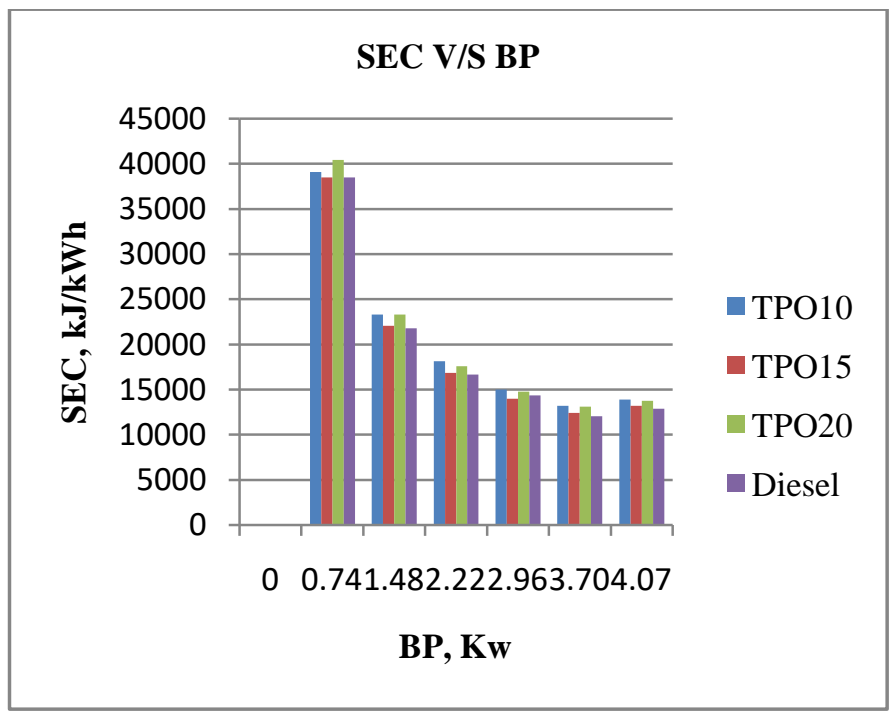

Fig. 5 Variations in Specific Energy Consumption with Brake Power

III Exhaust Gas Temperature:

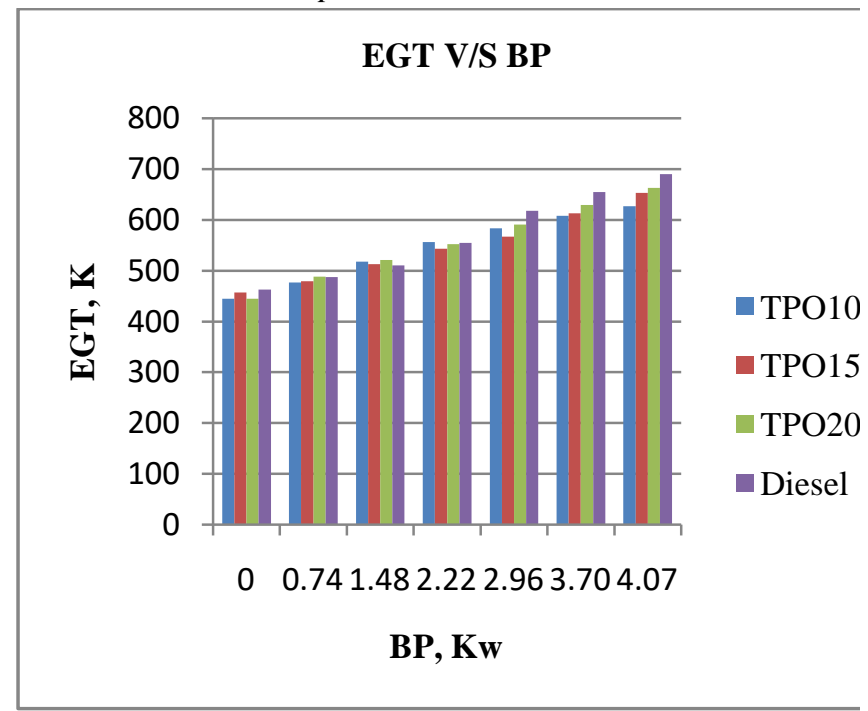

Fig. 6 Variations in Exhaust Gas Temperature with Brake Power

Figure.6 shows variation in Exhaust gas temperature with Brake power. It may be determined from the figure that the exhaust gas temperature is more or less same or less than that of diesel fuel. This may be due to better atomization and vapourization of TPO due to lower viscosity.

\section{B. Emission Characteristics}

\section{Carbon Monoxide:}

Figure.7 shows variation in Carbon Monoxide emission with Brake power. It may be determined from the figure that $\mathrm{CO}$ emission for TPO 10, TPO 15 and TPO 20 varies from 0.05 to

$0.09 \%$ which is slightly higher than that of diesel fuel but

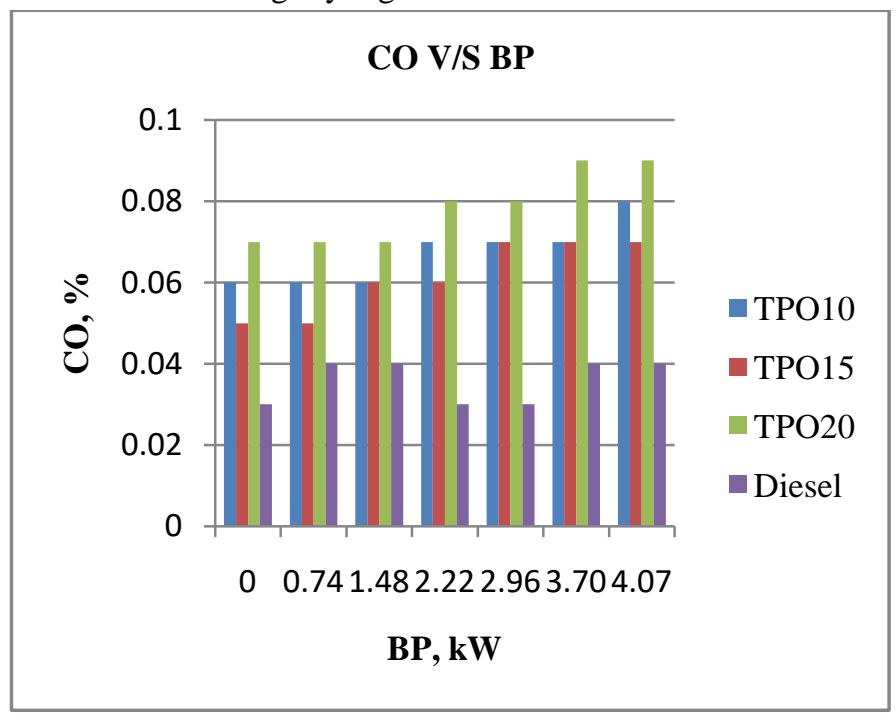

Fig. 7 Variations in Carbon Monoxide emission with Brake Power below Euro IV emission requirement. This may be due to rich air-fuel mixture at partial loads and volatility of TPO.

\section{Hydro Carbon:}

Figure.8 shows variation in hydrocarbon emission with brake power. It may be determined from the figure that hydrocarbon emission is higher for TPO 10, TPO 15 and TPO 20 as compared to diesel fuel.

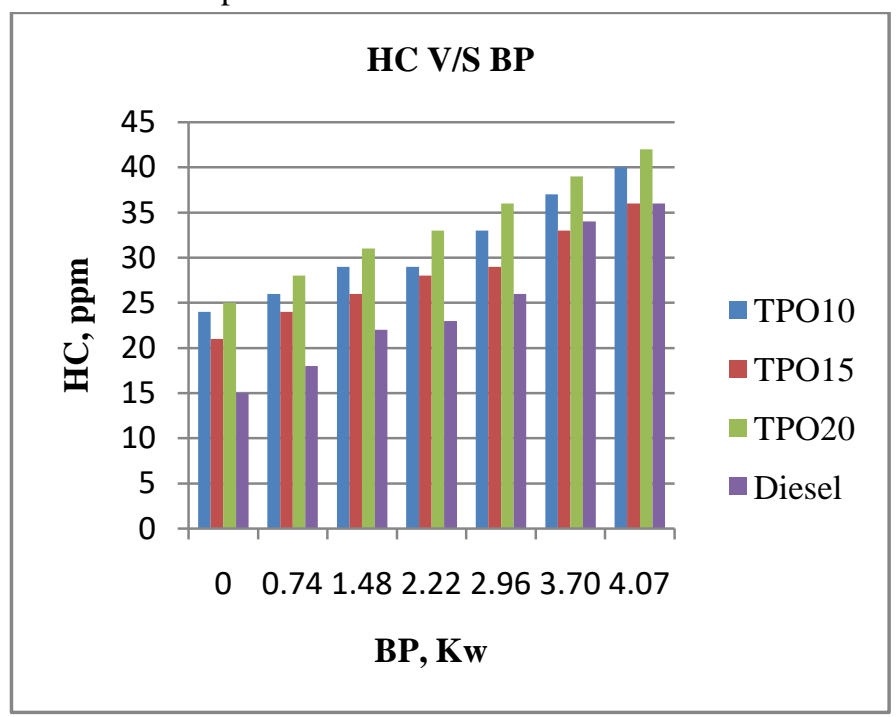

Fig. 8 Variations in Hydro Carbon with Brake Power

This may be due to unsaturated hydrocarbons present in TPO which are unbreakable during the combustion process ${ }^{[6]}$ as well as higher aromatic content of tyre pyrolysis oil. 


\section{Smoke Opacity:}

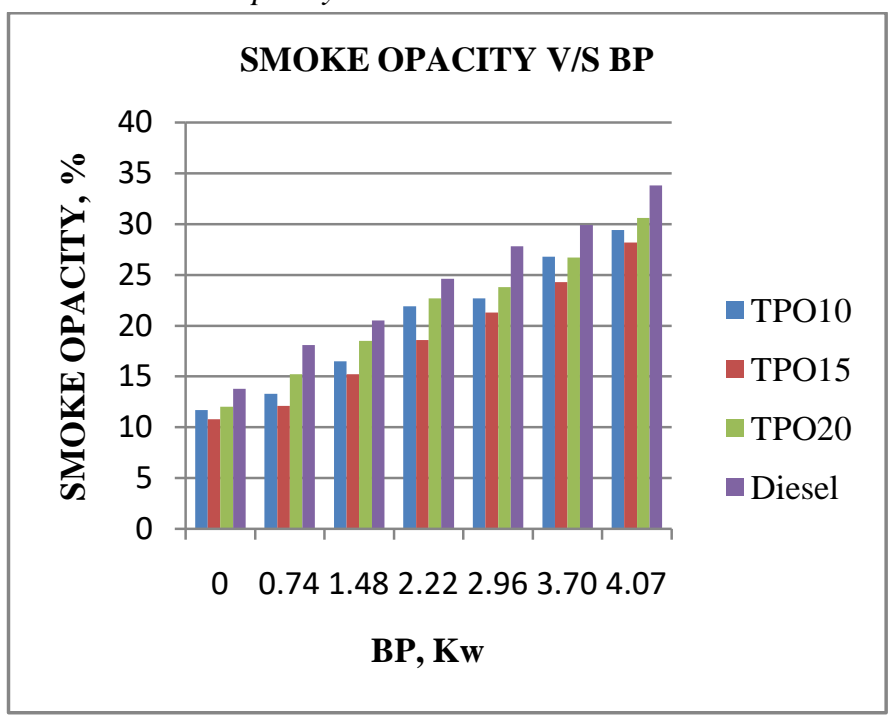

Fig. 9 Variations in Smoke Opacity with Brake Power

Figure. 9 shows variation in smoke opacity with Brake power. It may be determined from the figure that smoke opacity is lower for TPO 10, TPO 15 and TPO 20 as compared to diesel fuel. This may be due to finer fuel spray as well as higher temperatures during the expansion stroke and more time for oxidation of soot particles.

\section{CONCLUSIONS}

Based on the experimental investigations conducted on a single cylinder diesel engine using TPO-DF blend, the following major conclusions are observed.

- Brake thermal efficiency of the TPO - DF blend is 4 to $8 \%$ less than that of diesel fuel.

- $\mathrm{CO}$ emission is below the permissible limit for diesel engines.
- $\mathrm{HC}$ emission is higher by about 40 to $60 \%$ for TPO - DF blend as compared to DF for partial load, but for a full load as well as overload conditions it is higher by about $15 \%$ to $17 \%$ as compared to DF.

- Smoke opacity is lesser by about 14 to $22 \%$ for TPO - DF blend as compared to DF.

\section{REFERENCES}

[1] Cunnliffe. A.M., Williams. P.T. "Composition of oil derived from the batch pyrolysis of tyres", Journal of Analytical and Applied Pyrolysis 44, October 1997, pp.131-152.

[2] Roy C., Chaala A. and Darmstadt H "The Vacuum Pyrolysis of Used Tyres End use of oil and carbon black product", Journal of Analytical and Applied Pyrolysis 51, November 1998, pp. 201-221.

[3] Rodriguez I.M, Laresgoiti M.F, "Pyrolysis of scrap tyres", Fuel Processing Technology 72,February 2001, pp. 9-22

[4] Ucar S, Karagoz S, Ozkan A.R, and Yanik J, "Evaluation of two different scarp tyres as hydrocarbon source by pyrolysis," Fuel, vol. 84, 2005, pp. 1884-1892,

[5] Merchant, Petrich M.A, "Pyrolysis of scrap tyres and conversion of chars to activated carbon," AIChE Journal, vol. 39, 1993, pp. 1370-1376

[6] Eco Energy Solutions, "Power Generation by Scrap Tyres", January 2011, http://ecoenergysolutions.co.in/pdf/Pre project Report for Waste Tyre to Energy. PDF (f)

[7] Tamilvendhen D, Ilangovan V, Karthikeyan R, "Optimization of engine operating parameters for Eucalyptus oil mixed diesel fueled D I Diesel engine using Taguchi Method" ARPN Journal of Engineering and Applied Sciences, vol. 6, NO. 6, June 2011.

[8] Nagarajan G, Rao A.N, Renganarayanan S, "Emission and performance characteristics of neat ethanol fuelled DI diesel engine" International Journal of Ambient Energy., 2002, pp 149-158. 